\title{
Challenges in calibrating hydrological models to simultaneously evaluate water resources and flood hazard: a case study of Zou basin, Benin
}

\author{
${ }^{1}$ West Africa Science Service Centre on Climate Change and Adapted Land Use, University of Abomey-Calavi, PO Box 2008, Abomey-Calavi, \\ Benin Republic; *Corresponding author,E-mail: jeanhounkpe@gmail.com \\ ${ }^{2}$ Laboratory of Applied Hydrology, National Water Institute, University of Abomey-Calavi, PO Box 2008, Abomey-Calavi, Benin Republic \\ ${ }^{3}$ Department of Geography, University of Bonn, Meckenheimer Allee 166, Bonn 53115, Germany
}

(Received: August 6, 2016; Revised accepted: February 26, 2018)

http://dx.doi.org/10.18814/epiiugs/2018/018010

Under climate and land use changes, water cycle is expected to be intensified. This will likely result in frequent hydrometeorological extremes events such as droughts and floods, and affect the water balance components. A distributed model (WaSiM) was calibrated and validated to evaluate water resources and flood hazard in the Zou catchment, Benin, for the period 1991-2009. The model was calibrated and validated at a threshold of $120 \mathrm{~m}^{3} / \mathrm{s}$ and its performance in simulating lower discharge was evaluated. The results show that the model was able to satisfactory simulate streamflow using different thresholds with the Kling and Gupta efficiency (KGE) between 0.5 and 0.85. The model performance decreases with increasing discharge threshold. The overall water balance predicted by the model is consistent with the hydroclimatic condition of the basin. The runoff coefficient varies between $15 \%$ and $18 \%(11 \%$ and $14 \%$ respectively) of the total annual rainfall during the calibration (validation) period. By considering the discharge above the threshold of $120 \mathrm{~m}^{3} / \mathrm{s}$ the model performances were acceptable with regards to the uncertainties in discharge measurement mainly in peak discharge. Hence, the model is able to reproduce satisfactorily the hydrological processes in the study area and could be used for impact assessment.

\section{Introduction}

Changes in land use/land cover and climate systems are expected to speed up the water cycle. At the hydrological scale, potential impacts of these changes can be evaluated through watershed models. A number of hydrological model types have been developed in the last decades. The simplest type is the lumped model which describes the watershed as a single entity and it globalizes the hydrological process to its main features and has as input, mean or representative parameter values.
The more complex models are distributed models which consider spatial distribution of variables and reproduce the process in a watershed at a fine spatial resolution. In between these two types of models, are the semi-distributed models. These models subdivide the watershed into homogeneous units which are treated in a lumped manner. Lumped, semi-distributed or distributed models can be conceptual (meaning that the process description is not based on physical principles but on simplified descriptions) or physically based (most of its parameters are or can be derived from field measurement). Due to the increasing availability of data (soil, land use, DEM, etc.) and numerical facilities, more often distributed models are used. More details about hydrological modelling is given by Beven (2012). In recent years, distributed watershed models have been increasingly used to implement alternative management strategies for water resources allocation, flood control, land use and climate change impact assessments and pollution control (Shi et al., 2011). Before any impact study, models need to be calibrated and validated but this process is sometimes challenging due to different types of uncertainties. In addition, even if a model has been calibrated for a certain range of discharges, model output uncertainty is increasing when predictions are made outside this calibration range for extreme events. An experiment on 216 Australian catchments by Coron et al. (2012) indicated that "the transfer of model parameters in time may introduce a significant level of errors in simulations, meaning increased uncertainty in the various practical applications of these models (flow simulation, forecasting, design, reservoir management, climate change impact assessments, etc.)".

The calibration consists of getting the set of model parameters that outputs best match the observed data based on objective functions and visual inspection. The calibration of hydrological models can be done using manual or automatic approach or a combination of both methods. Depending on the optimization strategy and the objective function the optimum set of parameters automatically found may not necessarily reproduce the water balance component and the runoff components correctly. The modelling experiences and the author's knowledge on the basin are required and for that purpose, hybrid optimization strategies (manual and automatic calibrations) are recommended. Manag- 
ing risk in the short term is one of the most important applications of rainfall-runoff modelling, particularly for flood forecasting which requires decisions to be made as to whether flood warnings should be issued on the basis of the data coming in from rain gauges, radar rain- fall images, stream gauges and the model predictions as the event happens in "real time" (Beven, 2012). To assess the suitability of models to both well simulate water resources (water balance) and floods hazard (discharge at different thresholds), a distributed model (WaSiM)

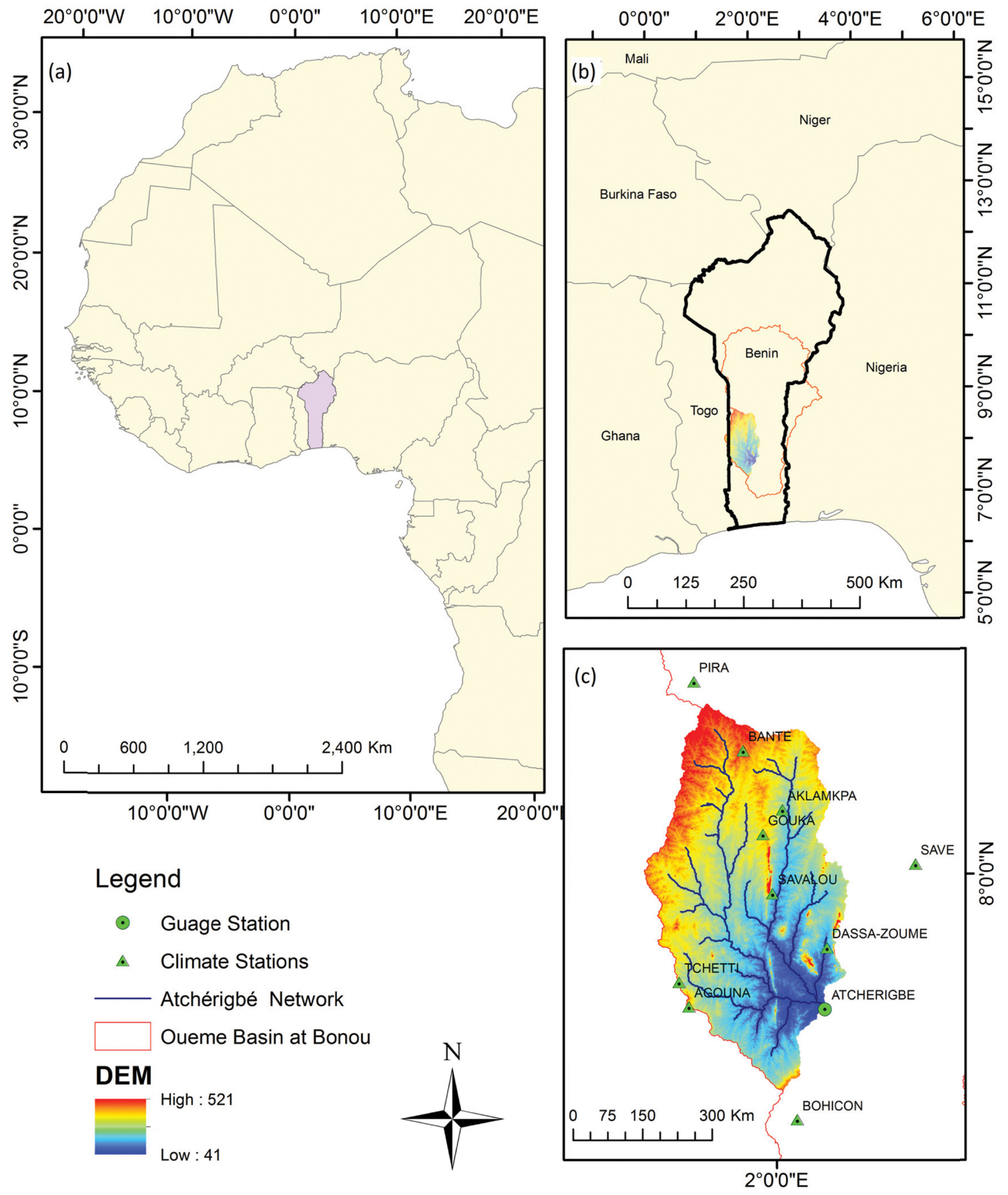

Figure 1. Overview of the Ouémé and Atchérigbé Catchments. (a) Location of Benin in Africa; (b) Location of the Ouémé and Atchérigbé Catchments in Benin; (c) Atchérigbé Catchment, its relief and the climate stations. 
(Schulla, 2012) has been considered. This model is widely used to assess water balance, climate change impact on hydrological cycle and water resources in West Africa (Kasei, 2009; Cornelissen et al., 2013). Besides, the WaSiM model is designed for flood simulation single event as well as continuous simulation of floods - (Schulla, 2012) and is successfully applied by some authors for flood modelling purpose (Jasper et al., 2002; Cullmann et al., 2006; Kunstmann et al., 2006; Herbst et al., 2009; Crochet, 2012). WaSiM simulates water quantity and can be used to evaluate the effects of land use change and human activities after calibration and validation. Experience suggests that uncertainty in both measurements and predictions of flood peaks increases with peak magnitudes (Beven, 2012). The aim of this work is to calibrate and validate WaSiM model for the Zou catchment and to evaluate its capacity in simulating simultaneously the high discharge at different threshold levels and the water balance.

\section{Study Area}

Benin Republic is located in West Africa between $06^{\circ} 00^{\prime}$ to $12^{\circ} 00^{\prime}$ northern latitude and $01^{\circ} 00^{\prime}$ to $03^{\circ} 40^{\prime}$ eastern longitude. The study area, the Atchérigbé basin, is a sub basin of the Ouémé basin (located at about $90 \%$ in Benin) and it has an area of 7035

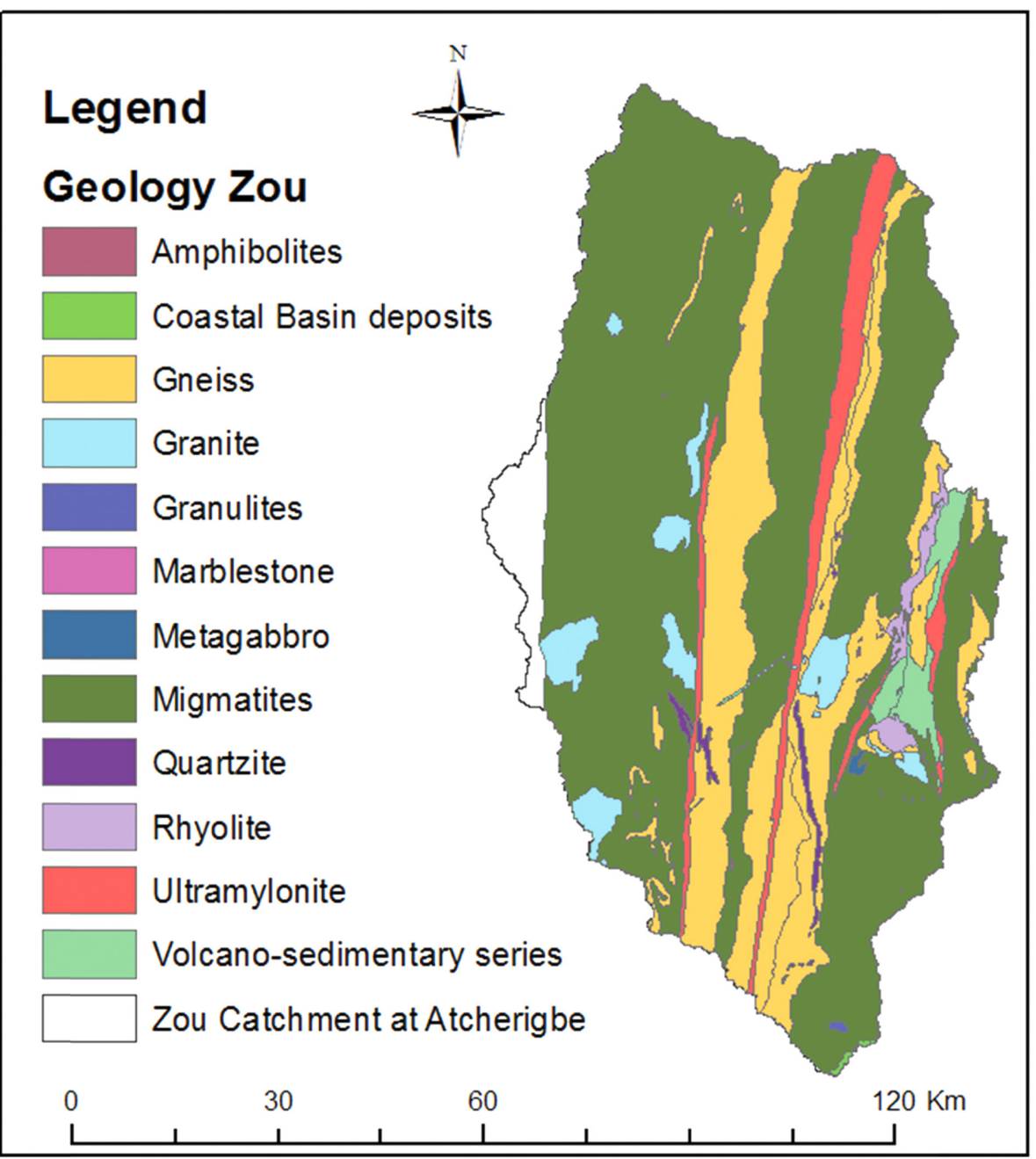

Figure 2. Geological map of Zou catchment, modified from Speth et al. (2010). $\mathrm{km}^{2}$ (Fig. 1).

Benin lies entirely in the tropical sub-Saharan region with a wet and dry climate. In the north of Benin, a semi-arid environment can be found, made up of savannahs and small mountains, while the south consists of a low coastal plain with marshlands, lakes and lagoons. Its climatic condition is typical of the West African climate, which alternates between the monsoon (from the ocean) during the cool and wet season, and the high thermal amplitude Harmattan wind that blows during the dry season from the Sahara (Aregheore, 2009).

The Ouémé basin is subdivided into three climatic zones according to different rainfall regimes: the north which has unimodal rainfall regime, the south which has bimodal rainfall regime and the middle which is a transition zone between the two previous regimes. The study area is located in this transition zone (between unimodal and bimodal rainfall regime). Rains mostly originate from the Guinean coast. Situated in a wet (Guinean coast) and a dry (Northern Soudanian zone) tropical climate, the Ouémé catchment records annual mean temperatures of $26^{\circ} \mathrm{C}$ to $30^{\circ} \mathrm{C}$, annual mean rainfalls of $1280 \mathrm{~mm}$ (from 1950 to 1969 ) and $1150 \mathrm{~mm}$ (from 1970 to 2004) at a climatic station close to $9^{\circ} \mathrm{N}$ latitude (Speth et al., 2010). In the Atchérigbé catchment, the average annual rainfall is $1162 \mathrm{~mm}$ for the period 1991 to 1998 and $1219 \mathrm{~mm}$ for 1999 to 2010 .

\section{Hydrogeology of the Study Area}

The geology of Benin consists of two main rock types: metamorphic/crystalline rocks and sedimentary rocks (Faure et al., 1998). Benin lies extensively on Precambrian crystalline basement, known as the Dahomeyides or the Benino-Nigerian shield. It consists predominantly of granites, granitoid gneisses, and gneisses. About $20 \%$ of Benin is occupied by sedimentary basins (ElFahem and Kocher, 2008). The Ouémé catchment mainly characterized by the Precambrian basement consists predominantly of complex migmatites granulites and gneisses, including less abundant mica shists, quarzites and amphibolites (Reichert et al., 2010 cited by Bossa (2012a)). The geological units that are dominant in the Zou catchment are migmatites and gneiss. The Precambrian consists predominantly of complex migmatites, granulites and gneisses, including less abundant quartzites and amphibolites. Synand post-tectonic intrusions of mainly granites, diorites and volcanic rocks are present (Wright and Burgess, 1992; Speth et al., 2010) (Fig. 2).

Barthel et al. (2008) show that the major faults (e.g., the Kandi fault system) dominate the tectonic situation in the northern part of Ouémé basin which includes our study area. Unweathered crystalline rocks with few fractures make poor aquifers. However, weathered granites and other $\mathrm{SiO}_{2}$-rich crystalline rocks can show a relatively high porosity and permeability. Fracture zones often lead to medium to high 


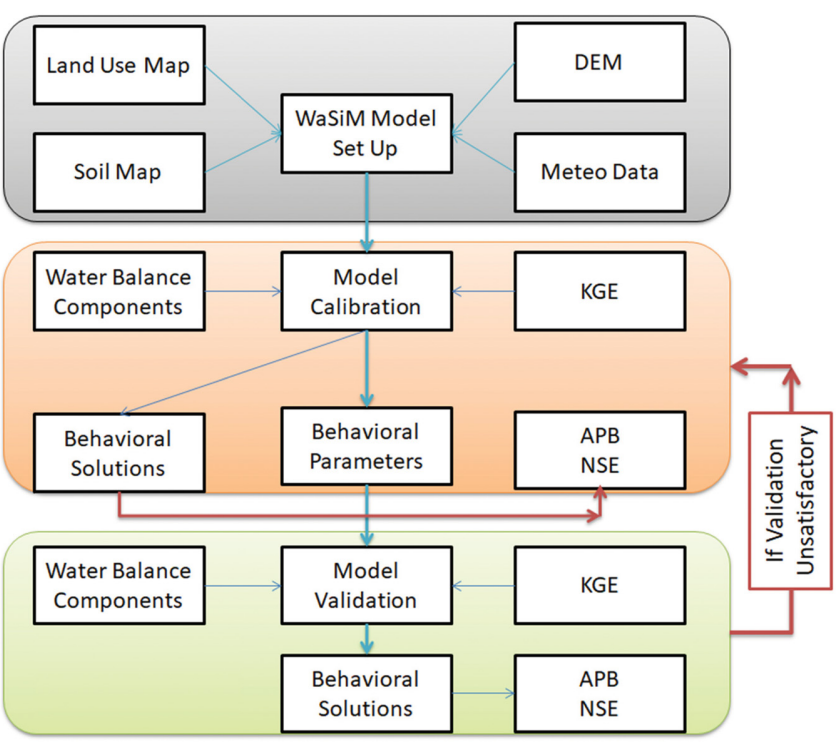

Figure 3. Methodological framework for model calibration and validation. The abbreviations are defined as: DEM: Digital Elevation Model, KGE: Kling and Gupta Efficiency, APB: Absolute Percentage Bias, NSE: Nash and Sutcliffe Efficiency.

hydraulic conductivities in the vicinity of faults. Altogether, zones of improved hydraulic properties (i.e., potential aquifers) are limited to the thin $(0$ to $20 \mathrm{~m})$ weathered zone and to the intensively fractured zones in the vicinity of major faults. According to Vouillamoz et al. (2014), the resulting groundwater bodies usually have a low storage capacity and are not connected to each other. Mean groundwater storage varies significantly from one geological unit to another, i.e., the higher storage value is about 2.5 times the lower one. However, variation in storage within the same geological unit can equal the variation among different units, suggesting that geological units are not the primary control on hydrogeological properties.

\section{Material and Method}

\section{Methodological Framework}

In WaSiM, the first step is to set up the model considering the digital elevation model (DEM), the hydrometeorological data, land use and soil data (Fig. 3, upper part). The next step is the model calibration at a threshold of $120 \mathrm{~m}^{3} / \mathrm{s}$. A semi-automatic calibration approach was adopted consisting of several runs of WaSiM model with parameter sets obtained using the Latin Hypercube Sampling (McKay et al., 2000). The best parameter sets denoted as 'behavioral parameters' were selected considering the KGE greater or equal to 0.5 and the corresponding water balance components in the range of what is regionally observed. After this selection, the Nash and Sutcliffe Efficiency and the Absolute Percentage Bias were computed for the behavioral solutions (simulated discharges with Kling and Gupta Efficiency greater or equal to 0.5 with acceptable water balance components) (Fig. 3, middle part). The last step was to validate the model considering the behavioral parameters previously obtained and the same constraint defined for the calibration. If the validation performances are not satisfactory, the calibration is resumed until satisfactory performances are obtained during both calibration and validation (see Fig. 3). Calibrating and validating the model at the threshold of $120 \mathrm{~m}^{3} / \mathrm{s}$ imply that it can be used for flood simulation (high discharge) and by accepting only behavioral solutions which water balance components are in line with the observation validate it use for that purpose.

\section{Model Inputs, Model Description and Model Setup}

Three data types (geographic, meteorological and hydrologic, see Table 1) are required for this study and they are compiled from different sources. The geographic data are required to represent spatial structures and time-invariant characteristics of the modelled area. They include the following: digital elevation model (DEM) SRTM at $90 \mathrm{~m}$ resolution (Jarvis et al., 2008), land use data obtained from Rivertwin project (RIVERTWIN, 2007) at $250 \mathrm{~m}$ resolution based on both satellite and in situ data, and soil data obtained from SOil and TERrain (SOTER) database established at a scale: 1:200,000 the whole Ouémé catchment, in cooperation with INRAB (Institut National de la Recherche Agricole du Bénin) (Bossa et al., 2014). This soil database was obtained through a combined approach of in situ measurement and remote sensing (satellite). The DEM is the basis for generating other derived data sets like sub-basins, river network, elevation, overland, channel lengths, channel slopes, etc. The soil data serve for deriving soil hydraulic properties like saturated conductivity, organic carbon, bulk density, texture, soil available water content, etc. The hydraulic properties were obtained from field work (Sintondji, 2005; Bossa,

Table 1. Description of the input data with the corresponding unit, period, frequency/resolution and source

\begin{tabular}{|c|c|c|c|c|c|}
\hline Data & Description & Unit & Period & Frequency/Resolution & Source \\
\hline \multirow{5}{*}{$\begin{array}{c}\text { Meteorological } \\
\text { Data }\end{array}$} & Rainfall & {$[\mathrm{mm} / \mathrm{day}]$} & \multirow{5}{*}{$1991-2009$} & \multirow{5}{*}{ Daily } & \multirow{5}{*}{$\begin{array}{l}\text { Direction Nationale de la Météorolo- } \\
\text { gie (DMN) of Benin Republic }\end{array}$} \\
\hline & Air Temperature & {$[\mathrm{C}]$} & & & \\
\hline & Sunshine Duration & {$[$ Hour $]$} & & & \\
\hline & Wind Speed & {$[\mathrm{m} / \mathrm{s}]$} & & & \\
\hline & Relative Humidity & {$[-]$} & & & \\
\hline \multirow{3}{*}{$\begin{array}{l}\text { Geographic } \\
\text { Data }\end{array}$} & Digital Elevation Model (DEM) SRTM & - & - & $90 \mathrm{~m}$ & Jarvis et al. (2008) \\
\hline & Land Use Data & - & 2003 & $250 \mathrm{~m}$ & RIVERTWIN (2007) \\
\hline & Soil Data & - & - & $1: 200,000$ & Soil and TERrain Database (SOTER) \\
\hline Hydrologic Data & Discharge & {$\left[\mathrm{m}^{3} / \mathrm{s}\right]$} & $1991-2009$ & Daily & Direction Générale de l'Eau of Benin \\
\hline
\end{tabular}


2012b) and using the pedo-transfer functions of Brooks \& Corey (1964). 40 different soil types have been identified in that basin. The dominant soil types are Albic Plinthosol (22\%), Mollic Gleysol (20\%), Ferric Luvisol (20\%) and Haplic Arenosols (15\%).

The catchment landscape is characterized by forest islands, gallery forest, savannah, woodlands, agricultural lands and pastures. Agriculture and other human activities have led to large-scale deforestation and fragmentations leaving only small relicts of the natural vegetation types within a matrix of degraded secondary habitats (Bossa, 2012, p. 10).

The meteorological data used are rainfall, air temperature, global solar radiation and/or sunshine duration, wind speed, relative humidity obtained from the national directorate of meteorology (Direction Nationale de la Météorologie, DMN). Global radiation was computed based on Amoussa (1992) using the sunshine duration and other parameters. In addition, discharge data were received from Benin's national water directorate (Direction Générale de l'Eau, DGEau). The geographic location of the stations is displayed on Figure 1.

WaSiM is a distributed, deterministic, mainly physically based hydrologic model (Schulla, 2012). It uses physically based algorithms for the vertical soil water fluxes and lateral groundwater fluxes. Lateral fluxes like surface runoff and interflow are treated in a conceptual manner. It can be applied from event-based to continuous simulations. The interpolation of rainfall was done using inverse distance weighting method and a value is automatically assigned to each grid cell based on the interpolated rainfall. As WASIM is a spatially distributed model, it was run at $0.25 \mathrm{~km}^{2}$ resolution. The hydrological processes are represented in WaSiM using different approaches which are enumerated in Table 2 below.

\section{Model Calibration and Performance Criteria}

A time period of 19 years were used for this simulation (1991-2009) at a daily time step. The calibration was done for 1999-2009 with four years of warm up. Thus, the computation of model performance during the calibration was done for the period 2005-2009. This corresponds to the period where we have less missing data compared to the validation period which is 1991-1998.

For model performance evaluation, three criteria are used. In the following equation, $Q_{s i m}^{(t h r)}$ is the simulated discharge above the threshold $t h r, Q_{o b s}^{(t h r)}$ is the observed discharge above the threshold $t h r, \mathrm{~N}$ is the total number of observation points and $i$ is a counter.

- The Kling and Gupta Efficient (KGE) (Gupta et al., 2009) consist of the linear correlation coefficient $r$ between observed and simulated discharge, the ratio $\alpha$ of the standard deviation of simulated discharge over the standard deviation of observed discharge and the ratio $\beta$ of the mean simulated discharge over the mean observed discharge. KGE ranges from $-\infty$ to 1 . The closer the KGE to 1 , the more accurate the model is. As explained by Gupta et al. (2009), the KGE is adapted for high discharge simulation when it is used for model calibration and validation.

$$
K G E=1-\sqrt{(r-1)^{2}+(\alpha-1)^{2}+(\beta-1)^{2}} .
$$

- For evaluating the long term simulation, the absolute percentage bias (APB) which is a measure for total volume differences between measured and observed data was used. This criterion is a performance for water balance simulation. The optimum value of APB is zero, meaning, as this criterion tend to zero, the total observed discharge tend to be equal to the total simulated discharge for the corresponding period. Nevertheless, APB less than $25 \%$ is generally accepted.

$$
A P B=\frac{\left|\sum_{i=1}^{N}\left(Q_{o b s}^{(t h r)}-Q_{s i m}^{(t h r)}\right)\right|}{\sum_{i=1}^{N} Q_{o b s}^{(t h r)}} .
$$

- The Nash and Sutcliffe Efficiency (NSE) (Nash and Sutcliffe, 1970). NSE ranges from $-\infty$ to 1 . An NSE of 1 corresponds to a perfect fit between observed and simulated discharge. An NSE equal to zero indicate that the model predictions does not perform better that the mean of the observed discharge. An NSE less than zero indicate that the mean of the observed data is better than model prediction. In sum, the closer the NSE is to 1 , the more accurate is the model prediction. The Nash and Sutcliffe Efficiency in this form is a good indicator for a good simulation of the mean discharge over an area.

$$
N S E=1-\frac{\left|\sum_{i=1}^{N}\left(Q_{s i m}^{(t h r)}-Q_{o b s}^{(t h r)}\right)\right|^{2}}{\sum_{i=1}^{N}\left(Q_{o b s}^{(t h r)}-{\overline{Q_{o b s}^{(t h r)}}}^{2}\right.} .
$$

Table 2. Hydrological processes and process representation of WaSiM $(L A I=$ leaf area index; PET = potential evapotranspiration); adapted from Cornelissen et al. (2013)

\begin{tabular}{|l|l|}
\hline Components & Approach used \\
\hline Interception & Storage approach; function of LAI \\
\hline Potential Evapotranspiration & Penman-Monteith (Monteith, 1975) \\
\hline Real Evapotranspiration & $\begin{array}{l}\text { Separate calculation of transpiration from vegetated soils considering all soil layers and evaporation } \\
\text { from bare soil for the first soil layer; both reduced by soil water content of the soil layers }\end{array}$ \\
\hline Soil module & Richards equation \\
\hline Infiltration & Richards equation \\
\hline Overland flow & Horton overland flow \\
\hline Percolation & Function based on soil saturation and saturated conductivity \\
\hline Interflow & Storage approach; comparing maximum and actual rate \\
\hline Base flow & Linear storage approach \\
\hline Routing & Kinematic wave approach considering retention and translation \\
\hline
\end{tabular}




\section{Results and discussions}

\section{Model Calibration Statistics}

The model was calibrated and validated at the threshold of $120 \mathrm{~m}^{3} / \mathrm{s}$ and its performance was evaluated in simulating discharge under other thresholds (less than $120 \mathrm{~m}^{3} / \mathrm{s}$ ). Care was taking for the simulation of water balance components. The calibration of the hydrological process model in this catchment was done using daily observed river discharge for comparison. The observed runoff coefficient (quotient of the mean annual discharge and the mean annual rainfall) referred to as CoefRun and the coefficient of real evapotranspiration (ETR) (quotient of mean annual ETR and the mean annual rainfall) referred to as CoefETR derived from previous works done in similar climate conditions to our study area were used as qualitative information.

The model calibration and validation was done by considering only the observed discharge above the threshold of $120 \mathrm{~m}^{3} / \mathrm{s}$ which corresponds to $1.5 \mathrm{~mm} /$ day using the KGE for optimization criteria. Figure 4 shows the KGE, the NSE and the APB for each of the behavioral run for different thresholds. Acceptable results were found with KGE reaching 0.58 and the percentage biases of most of the simulation were lower than $20 \%$ at the calibrated threshold of $120 \mathrm{~m}^{3} / \mathrm{s}$. For thresholds lower than $120 \mathrm{~m}^{3} / \mathrm{s}(1.5 \mathrm{~mm} /$ day $)$, the KGE is higher reaching a value of 0.81 at the threshold of $0 \mathrm{~m}^{3} / \mathrm{s}$ (using all discharge data). This implies that by concentrating the calibration on the discharge greater than a given threshold, the other parts of the hydrograph are by the same time well simulated. It is of interest to note that despite the poor quality of the simulations according to the NSE at the threshold of 120 $\mathrm{m}^{3} / \mathrm{s}$, the same criteria shows very good simulation at lower threshold reaching the value of 0.76 at the threshold of $0 \mathrm{~m}^{3} / \mathrm{s}$. By the time the KGE criterion is considering a simulation as acceptable, the NSE criteria may consider it as poor simulation at high threshold. This implies that using the NSE as optimization criteria for flood simulation purpose lead to underestimation of the peak discharges but with the KGE, this underestimation will not be as severe compared to the NSE.

As far as the percentage bias (PBias) is concerned, there is no straight forward conclusion about whether calibrating a model at a giving threshold implies a good simulation for lower thresholds. Considering the median (Fig. 4, left, black dotted line), PBias decreases from the threshold of $120 \mathrm{~m}^{3} / \mathrm{s}$ and reaches its optimum value at the threshold of $20 \mathrm{~m}^{3} / \mathrm{s}$ and it continue to decrease up to the threshold of $0 \mathrm{~m}^{3} / \mathrm{s}$. In absolute value, the PBias is smaller at the calibration threshold than at the threshold of 0 .
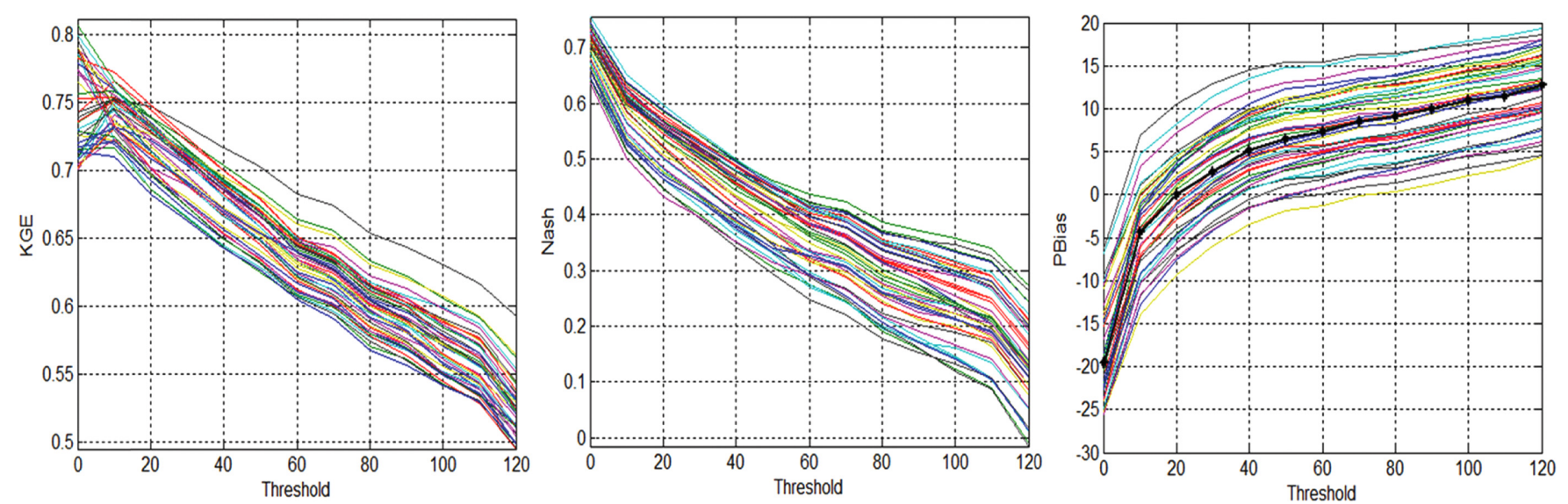

Figure 4. Model performance for different thresholds considering each behavioral run during calibration at the threshold of $120 \mathrm{~m}^{3} / \mathrm{s}$.
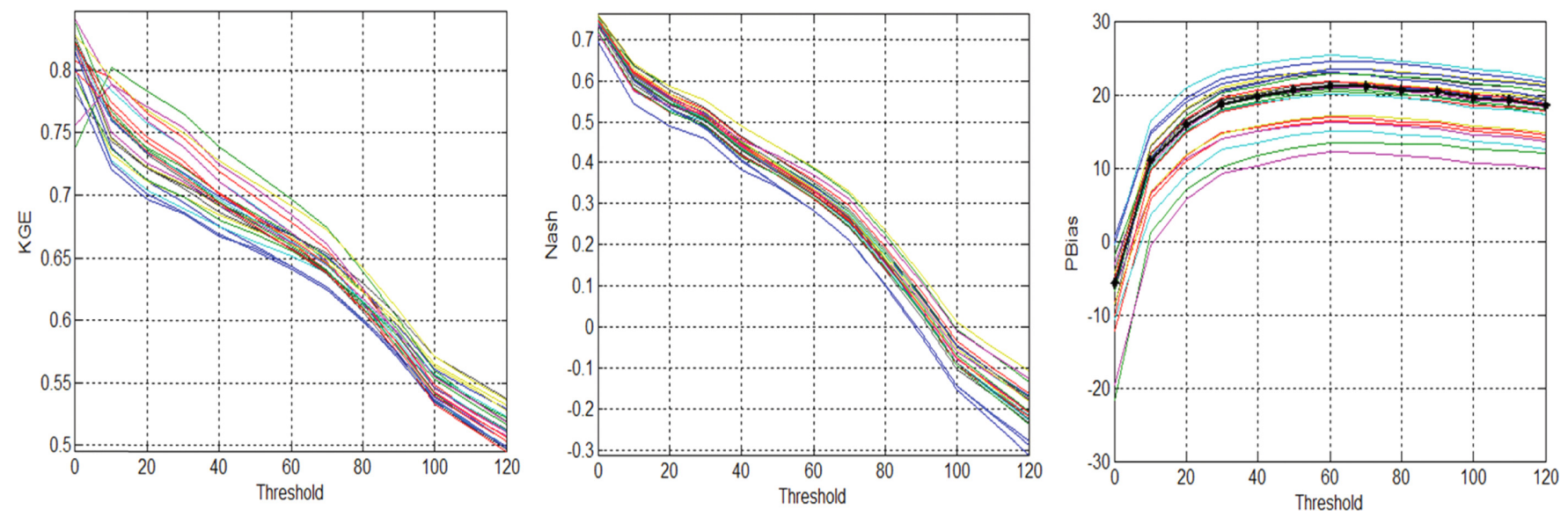

Figure 5. Model performance for different thresholds considering each behavioral run during validation at the threshold of $120 \mathrm{~m}^{3} / \mathrm{s}$. 


\section{Model Validation Statistics}

As far as the validation is concerned (Fig. 5), WaSiM performed acceptably with KGE greater than 0.5 at the threshold of $120 \mathrm{~m}^{3} / \mathrm{s}$. At smaller thresholds, the KGE increases up to 0.85 when considering the whole hydrograph. The smaller the threshold, the higher is the model performance. As it was observed during the calibration, NSE was very small (negative in this case) at the threshold of $120 \mathrm{~m}^{3} / \mathrm{s}$ while at the threshold of 0 , the same simulations were found by the same criteria to be good (NSE up to 0.76 ). We can conclude that simulations which are found by the NSE as good while considering the whole hydrograph does not imply good simulation for higher thresholds. By considering the KGE as optimization criteria, the chance of getting good simulation for different thresholds is higher than using the NSE as optimization criteria.

\section{Observed and Simulated Discharge by WaSiM}

The observed and simulated discharges for the calibration and validation periods are shown on Figure 6. It can be observed that during both the calibration and validation periods, the model simulated acceptably the discharge but the high discharges for some years were

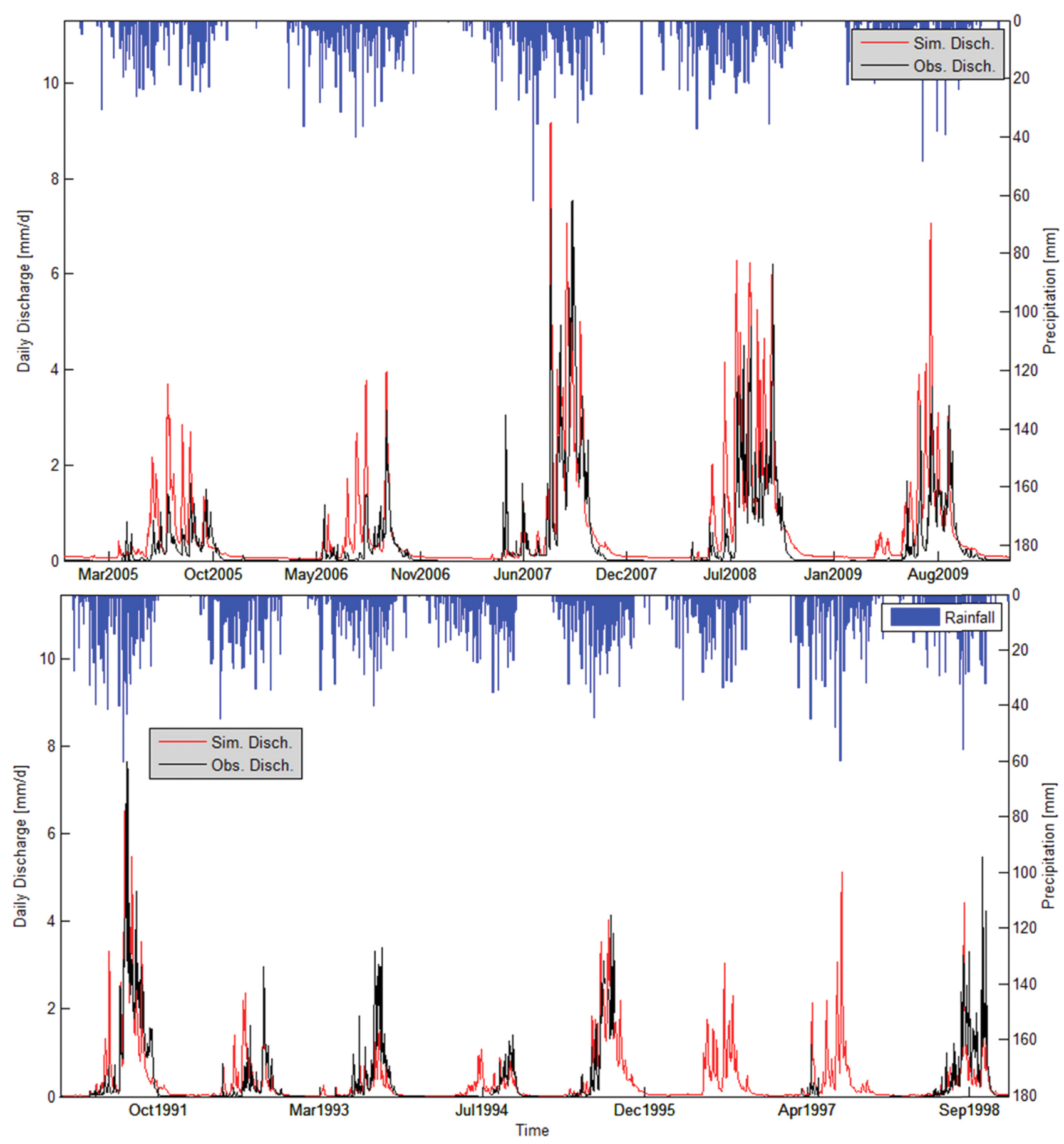

Figure 6. Observed and simulated discharge for the calibration (upper) and the validation (down). 


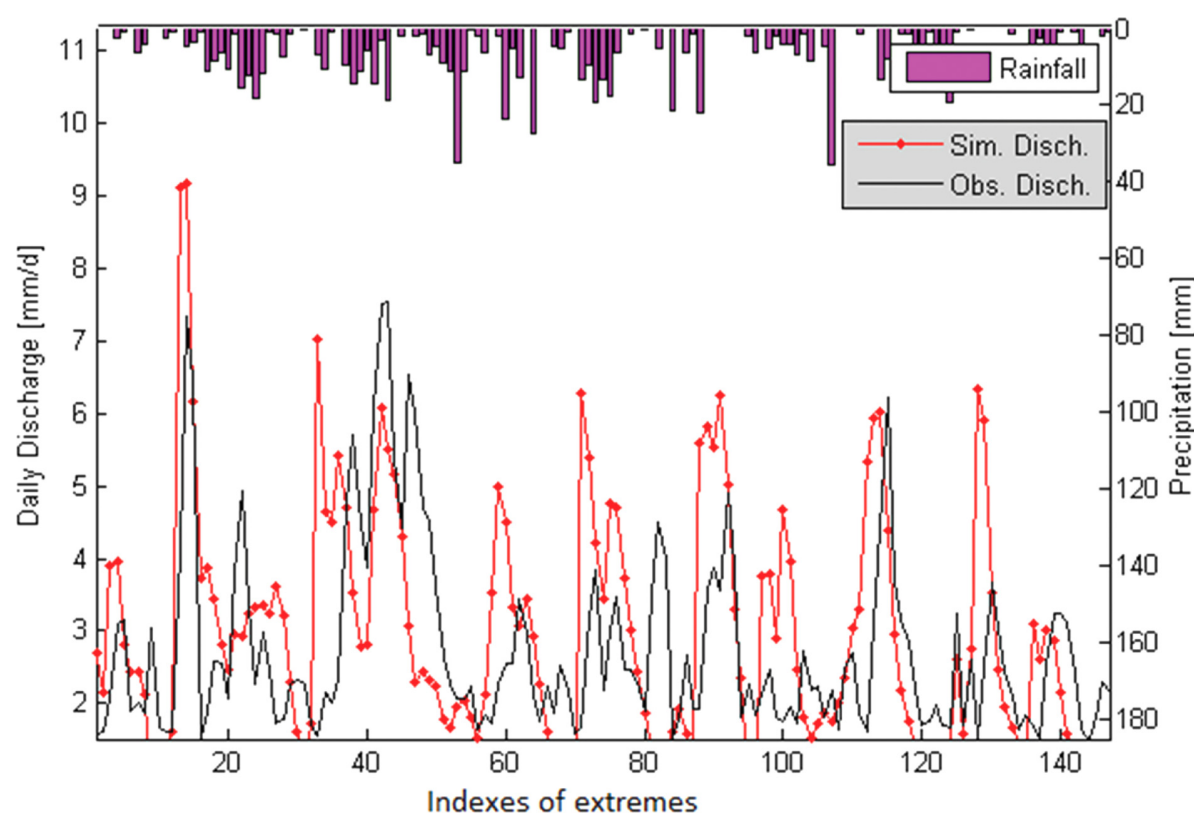

Figure 7. Observed and simulated high discharge (greater or equal to $120 \mathrm{~m}^{3} / \mathrm{s}$ or $1.5 \mathrm{~mm} / \mathrm{day}$ ) by WaSiM.

underestimated mainly during the validation period. This may be due to the quality of the data used. In addition, the computation of discharge from observed water levels using the rating curve are bound to many uncertainties mainly for the peak discharges.

The observed and simulated discharges above the threshold of $120 \mathrm{~m}^{3} / \mathrm{s}$ are shown on (Fig. 7). Some of the peaks are well simulated but the model fails to reproduce other peaks. Data quality is a critical issue and even more concerning the high discharge when performing hydrological modeling. Experience suggests that uncertainty in both measurements and predictions of flood peaks increases with peak magnitudes (Beven, 2012). Therefore, it cannot be expected that the simulated discharge peaks will match exactly the observed peaks. The standard practice is to match as well as possible the two signals. Generally, the models acceptably represent the variability in the

observed high discharge over the basin.

Generally, stage-discharge rating curves are obtained by extrapolation when a water level is recorded below the lowest or above the highest gauged level. Large errors can result from extrapolation of ratings beyond the range of gauged discharges without consideration of cross-section geometry and controls (Mosley and McKerchar, 1993; Legesse et al., 2003). In fact, during the high discharge period, the water may overflow the stream channel complicating the reliability of the stage-discharge relationship and leading to underestimation of high discharges. Using these discharges during rainfallrunoff modelling will necessarily impact on the performance of the simulation. This may explain the moderate performance of the hydrological model in simulating the high discharge in the Zou catchment.

\section{Water Balances}

The overall water balance predicted by the model is consistent with the hydroclimatic condition of the basin (Table 3). The interpolated mean annual rainfall computed by WaSiM was $1179 \mathrm{~mm}$ for calibration period and $1158 \mathrm{~mm}$ for the validation period. The real evapotranspiration (ETR) coefficient predicted by the model was around $84 \%$ ( $87 \%$ respectively) of the rainfall and the runoff coefficient was

Table 3. Mean performance criteria and mean water balance components as simulated by WaSiM model during the calibration period (2005:2009) and the validation period (1991:1998) with a threshold of $120 \mathrm{~m}^{3} / \mathrm{s}(1.5 \mathrm{~mm} /$ day) based on 10 behavioral simulations

\begin{tabular}{|c|c|c|c|c|c|c|}
\hline & \multicolumn{3}{|c|}{ Calibration } & \multicolumn{3}{|c|}{ Validation } \\
\hline & Min & Mean & Max & Min & Mean & Max \\
\hline KGE & 0.50 & 0.54 & 0.60 & 0.50 & 0.52 & 0.54 \\
\hline APB & 0.32 & 3.39 & 8.21 & 9.85 & 16.04 & 19.44 \\
\hline CoefRun & 15.24 & 16.14 & 18.00 & 11.46 & 12.24 & 13.68 \\
\hline CoefETR & 82.13 & 83.92 & 84.86 & 85.84 & 87.10 & 87.81 \\
\hline Rainfall & 1179 & 1179 & 1179 & 1158 & 1158 & 1158 \\
\hline Total Runoff & 180 & 190 & 212 & 133 & 142 & 158 \\
\hline Interflow & 139 & 151 & 164 & 102 & 110 & 122 \\
\hline Overland & 13 & 17 & 21 & 10 & 12 & 16 \\
\hline Baseflow & 12 & 22 & 35 & 10 & 20 & 30 \\
\hline ETR & 968 & 989 & 1000 & 994 & 1008 & 1017 \\
\hline ETP & 2239 & 2306 & 2344 & 2248 & 2317 & 2357 \\
\hline Storage & -5 & -1 & 2 & 5 & 8 & 9 \\
\hline
\end{tabular}

ETR: real evapotranspiration; ETP: potential evapotranspiration; APB: absolute percentage bias.

CoefRun (CoefETR) is the percentage of the mean annual discharge (ETR respectively) to the mean annual rainfall. 
around $16 \%$ (12\% respectively) during the calibration (validation respectively). In this study, the main water balances components computed by WaSiM are the rainfall, the ETR, the discharge and the variation of the storage. The mean predicted water balance for the calibration and validation periods is in line with what is regionally observed (Bossa, 2012b). According to Diekkrüger et al. (2010), the runoff coefficients within the Ouémé basin vary between 0.10 and 0.26 with the lowest value for savannahs and forests. In accounting for the uncertainty in discharge measurement particularly for high discharge and the performance criteria, we can deduce that the model reproduces acceptably the runoff and it process over the study area.

Different fractions of discharge components were obtained. The proportion of the three components of the runoff (surface runoff, interflow, and baseflow) depends on the physical characteristics of the watershed, the land use and the soil characteristics. According to WaSiM, the interflow is the dominant runoff component in the study area. This fact was also observed by previous studies in Ouémé Catchment (Sintondji, 2005; Giertz et al., 2006; Cornelissen et al., 2013).

The interflow represented respectively $79 \%$ and $77 \%$ of the total runoff during calibration and validation. The simulated percentages of baseflow which preserves the discharge during the dry season are respectively $12 \%$ and $14 \%$ of the total discharge during calibration and validation. Similar results were obtained by Legesse et al. (2003) for a catchment located in central Ethiopia (tropical catchment) for which around $10 \%$ of the total runoff was simulated as overland flow. The contribution of the overland flow is relatively small and can be explained by the absence of impervious zone in the catchment otherwise the quick flow would have been higher. The mainly cultivated/ grazing land in the watershed favors infiltration in the soil zone and thereby lateral subsurface flow along subsurface channels, macro pores, and fractures (Legesse et al., 2003) and this would explain the relatively small contribution of overland flow to the streamflow.

\section{Conclusions}

In this study, we evaluated the performance of WaSiM model in simulating discharge over the Atchérigbé basin. The calibration and validation of this model is necessary and prior to their use for any impact assessment. Statistical and graphical methods were used for model performances evaluation. The WaSiM model was successfully calibrated and validated for the study area during the period 1991-2009 with the KGE greater than 0.5 for calibration and validation periods at different thresholds. Based on the previous studies in the region, WaSiM successfully simulated the water balance of the study area. Due to the uncertainties in discharge measurement and mainly in the peaks estimated from the rating curve, the model performances were not as good for high discharge as for the whole hydrograph. Nevertheless, we realized that by calibrating the models on high discharge above a given threshold, the discharge which are below this threshold are by the same time well simulated. We recommend therefore, the calibration of hydrological models considering discharges threshold different from zero. Obtaining good model performances during calibration and validation based on performance criteria does not necessary imply a good water balance simulation. It is hence advised to account for the water balance components while calibrating hydrological models.
Overall, the model is able to reproduce satisfactorily the hydrological processes in the study area and could be used for impact assessment.

\section{Acknowledgements}

This work has been funded by the German Federal Ministry of Education and Research (BMBF) through the West African Science Service Centre on Climate Change and Adapted Land Use (WASCAL).

\section{References}

Amoussa, S., 1992, Estimation of global solar radiation in Benin: renewable. Energy, v. 2, pp. 311-317.

Aregheore, E.M., 2009, Country Pasture/Forage Resource Profiles, The Republic of Benin. www.fao.org/ag/agp/agpc/doc/counprof/benin/Benin.htm [accessed $14^{\text {th }}$ February 2016]

Barthel, R., Jagelke, J., Gotzinger, J., and Gaiser, T.Z.A., 2008, Aspects of choosing appropriate concepts for modelling groundwater resources in regional integrated water resources management - examples from the Neckar (Germany) 'me' catchment (Benin) and Oue. Physics and Chemistry of the Earth, v. 33, pp. 92-114. DOI: 10.1016/j.pce.2007.04.013

Beven, K., 2012, Rainfall-Runoff Modelling: the Primer ( $2^{\text {nd }}$ edition). JohnWiley \& Sons, Oxford, $472 \mathrm{p}$.

Bossa, A., Diekkrüger, B., and Agbossou, E., 2014, Scenario-based impacts of land use and climate change on land and water degradation from the meso to regional scale. Water v. 6, pp. 3152-3181. DOI: 10.3390/w6103152

Bossa, Y.A., 2012, Multi-scale modeling of sediment and nutrient flow dynamics in the Ouémé catchment (Benin) - towards an assessment of global change effects on soil degradation and water quality. Ph.D. Thesis, University of Bonn, Bonn, $110 \mathrm{p}$.

Cornelissen, T., Diekkrüger, B., and Giertz, S., 2013, A comparison of hydrological models for assessing the impact of land use and climate change on discharge in a tropical catchment. Journal of Hydrology, v. 498, pp. 221-236. DOI: 10.1016/j.jhydrol.2013.06.016

Coron, L., Andreassian, V., Perrin, C., Lerat, J., Vaze, J., Bourqui, M., and Hendrickx, F., 2012, Crash testing hydrological models in contrasted climate conditions: an experiment on 216 Australian catchments. Water Resources Research. v. 48, pp. 1-17. DOI: 10.1029/2011WR011721

Crochet, P., 2012, Flood-Duration-Frequency modeling application to ten catchments in Northern Iceland. Report. URL http://www.vedur.is/media/ 2012_006.pdf, [accessed $8^{\text {th }}$ March 2016].

Cullman, J., Mishra, V., and Peters, R., 2006, Flow analysis with WaSiMETH - model parameter sensitivity at different scales. Advances in Geosciences, v. 9, pp. 73-77.

Diekkrüger, B., Busche, H., Giertz, S., and Steup, G., 2010, Hydrology. In: Speth, P., Christoph, M., and Diekkrüger, B. (Eds.), Impacts of Global Change on the Hydrological Cycle in West and Northwest Africa. Springer, Heidelberg, pp. 60-69.

El-Fahem, T., and Kocher, A., 2008, Geology of the Ouémé Catchment. In: Judex, M., and Thamm, H.-P. (Eds.), IMPETUS Atlas Benin. Research Results 2000-2007 ( $3^{\text {rd }}$ edition). Department of Geography, University of Bonn, Bonn, 65 p.

Faure, P., Volkoff, B., Eschner, A.R., Trimble, S.W., and Angeles, L., 1998, Some factors affecting regional differentiation of the soils in the Republic of Benin (West Africa). Catena, v. 32, pp. 281-306.

Gupta, H.V., Kling, H., Yilmaz, K.K., and Martinez, G.F., 2009, Decomposition of the mean squared error and NSE performance criteria: implications for improving hydrological modelling. Journal of Hydrology, v. 377, pp. 80-91. DOI: 10.1016/j.jhydrol.2009.08.003

Herbst, M., Casper, M.C., Grundmann, J., and Buchholz, O., 2009, Comparative analysis of model behaviour for flood prediction purposes using 
self-organizing maps. Natural Hazards and Earth System Science, v. 9, pp. 373-392. DOI: 10.5194/nhess-9-373-2009

Jarvis, A., Reuter, H.I., Nelson, A., and Guevara, E., 2008, Hole-filled seamless SRTM data V4. International Centre for Tropical Agriculture (CIAT). www.cgiar-csi.org/data/srtm-90m-digital-elevation-database-v4-1 [accessed $5^{\text {th }}$ March 2013].

Jasper, K., Gurtz, J., and Lang, H., 2002, Advanced flood forecasting in Alpine watersheds by coupling meteorological observations and forecasts with a distributed hydrological model. Journal of Hydrology, v. 267, pp. 40-52. DOI: 10.1016/S0022-1694(02)00138-5

Kasei, R.A., 2009, Modelling impacts of climate change on water resources in the Volta Basin, West Africa. Ph.D. Thesis, University of Bonn, Bonn, 184 p.

Kunstmann, H., Marx, A., Werhahn, J., and Smiatek, G., 2006, Early flood warning for Alpine catchments through coupled precipitation/river runoff - forecasts. http:/www.univie.ac.at/IMG-Wien/meetings/map_dphase/abstracts/20-floodwarn-marx.pdf [accessed 05 ${ }^{\text {th }}$ March 2015]

Legesse, D., Vallet-Coulomb, C., and Gasse, F., 2003, Hydrological response of a catchment to climate and land use changes in Tropical Africa: case study Ssouth Central Ethiopia. Journal of Hydrology, v. 275, pp. 67-85. DOI: 10.1016/S0022-1694(03)00019-2

McKay, M.D., Beckman, R.J., and Conover, W.J., 2000, A comparison of three methods for selecting values of input variables in the analysis of output from a computer code. Technometrics, v. 42, pp. 55-61.

Monteith, J., 1975, Vegetation and the Atmosphere: 1. Prinicples. Academic Press, London, 278 p.

Mosley, M., and McKerchar, A., 1993, Streamflow. In: Maidment, D. (Ed.), Handbook of Hydrology. McGraw-Hill Inc., New York, pp. 8.1-8.39.

Nash, J.E., and Sutcliffe, J.V., 1970, River flow forecasting through conceptual models: Part I - a discussion of principles. Journal of Hydrology, v. 10, pp. 282-290.

RIVERTWIN, 2007, Regional model for integrated water management in twinned river basins: adapted and integrated model for the Ouémé River Basin. Final Report, Institute for Landscape Planning and Ecology, Stuttgart. http://cordis.europa.eu/publication/rcn/11810_de.html [accessed $06^{\text {th }}$ May 2015]

Schoenau, S., Thapa, P., and Bárdossy, A., 2008, Erosion and sediment yield estimation for flood protection. $4^{\text {th }}$ International Symposium on Flood Defense: Managing Flood Risk, Reliability and Vulnerability, Toronto, pp. 1-8.

Schulla, J., 2012, Model Description WaSiM. Hydrology Software Consulting, Zürich, $305 \mathrm{p}$.

Shi, P., Chen, C., Srinivasan, R., Zhang, X., Cai, T., Fang, X., Qu, S., Chen, X., and Li, Q., 2011, Evaluating the SWAT model for hydrological modeling in the Xixian watershed and a comparison with the XAJ model. Water Resources Management, v. 25, pp. 2595-2612. DOI: 10.1007/ s11269-011-9828-8

Sintondji, L.O.C., 2005, Modelling the rainfall-runoff process in the Upper Ouémé catchment (Terou in Bénin Republic) in a context of global change : extrapolation from the local to the regional scale. Ph.D. Thesis. University of Bonn, Bonn, $205 \mathrm{p}$.

Speth, P., Christoph, M., and Diekkrüger, B. (Eds.), 2010, Impacts of Global Change on the Hydrological Cycle in West and Northwest Africa. Springer, Berlin, $675 \mathrm{p}$.

Vouillamoz, J.M., Lawson, F.M.A., Yalo, N., and Descloitres, M., 2014, Groundwater in hard rocks of Benin: regional storage and buffer capacity in the face of change. Journal of Hydrology, v. 24, pp. 1-25. DOI: $10.1016 /$ j.jhydrol.2014.11.024

Wright, E., and Burgess, W. (Eds), 1992, The Hydrogeology of Crystalline Basement Aquifers in Africa. Geological Society of London, Special Publication, no. 66, 264 p.

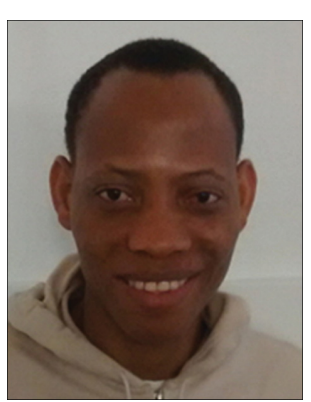

Jean Hounkpè is a researcher in hydrology at National Water Institute, University of Abomey-Calavi (Benin Republic, West Africa). He defended his $\mathrm{PhD}$ in the field of climate change and water resources with a focus on extreme events. His interests include hydrological modelling, statistical hydrology, and assessment of global change impact on flood risk and water resources. He is currently working on the development of a complete chain for flood risk assessment in Ouémé basin (Benin Republic) which can be transferred to other basins in the country and abroad.

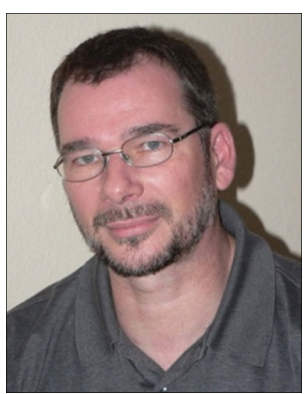

Bernd Diekkrüger is a professor for hydrology at the Department of Geography, University of Bonn, Germany. His professional interests include analysis and modelling of water, sediment and solute transport at different spatial (from point to regional) and temporal (from single events to decades) scale. His focus is on the analysis of the effects of global change on water and soil resources with a regional focus in Africa. The strength of the his research experience can be characterized in linking computer science (development of environmental models as well as Decision Support Systems) with process analysis and the ability for interdisciplinary cooperation. 